\title{
THE SCIENCE OF NURSING: CURRENT ISSUES AND DILEMMAS
}

\section{H. Brink}

\begin{abstract}
The question regarding the nature and direction of nursing science, how it is derived or why and whether nursing is a science is a much debated one. This article focuses on an examination of the literaure with regard to conceptualisations of science in general and nursing in particular with special emphasis on the nature, purpose, methods and domain of science and nursing science. It looks at the various positions taken, examines the consequences of holding any special position and makes suggestions for achieving excellence in Nursing Science.

\section{Opsomming}

Die aard van wetenskapsbeoefening in die verpleegkunde, die rigting wat dit behoort te volg, die metodes van kennisversameling en die bestaansreg van die verpleegkunde of hoekon dit well as wetenskap kwalifiseer, is almal omstrede vraagstukke in die verpleegliteratuur. Die literatuur met betrekking cot bogenoemde aspekte is verken en aspelte ten opsigte van die konseptualisering van die wetenskap in die algemeen en meer speisfiek die verpleegkunde as ' $n$ wetenskap, word bespreek. Daar word veral aandag gegee aan die aard, doeh, metodes en domein van die wetenskap en verpleging as ' $n$ wetenskap. Verskillende standpunte rakende hierdie aspekte word onder die loep geneem. Aandag word ook gegee aan gevolge, indien 'n sekere standpunt gehuldig word. Voorstelle hoedate uitnuntendheid in verpleegkunde bereik kan word, word gemaak.
\end{abstract}

\section{INTRODUCTION}

Nursing has long been considered as an art, whereas nursing as a science is a relatively recent development. Other than Nightingale who in 1860 identified nursing as both an art and science not valuing one more than the other, (Nightingale reprinted 1969) it was not until the late 1950 's that serious attention was given to nursing as a science. Since that time nursing increasingly has become concerned about its knowledge base for practice. Today the term nursing science is familiar to nurses. Contemporary literature abounds with strategies for building a nursing science (Chinn \& Jacobs 1987; Jacox 1974; Watson 198.). There are Departments of Nursing Science and the South African Nursing Council (SANC) describes nursing as a human clinical health science.

There are, however, critics who challenge the view that nursing is a science, and nurses are not always able to present convincing arguments that nursing in fact is a science. Even among nurses themselves there is not al ways agrecment on the nature and direction of nursing science or how it is derived, or why nursing is a science. For close on thirty years this has been a subject of debate among nurse scholars, and contrary positions still are being explicated.

In order to be able to participate meaningfully in such debates or defend their views when challenged, it is essential for nurses to have an understanding of the nature of nursing science and how it relates to the larger body of science, to be exposed to different viewpoints and to be able to judge the relative merits of arguments related to nursing as a science.

This article seeks to examine conceptualisations of science in general and nursing science in particular, as presented in the literature, with regard to its nature, purpose, methods and domain. It will also look at the various positions taken, examine the consequences of holding any special position, make suggestions for achieving excellence in nursing science and thereby try to clarify the issues relating to nursing as a science.

\section{WIIAT IS SCIENCE?}

The question "What exactly is science?" is not easy to answer. Many and varied ideas, attitudes and conceptualisations on the exact nature of science and knowing can be found in the literature, each reflecting a specific world view. Science has been defined as a product, a process or both. As a product, science represents the evergrowing, everchanging accumulated knowledge of a particular discipline (Abdellah 1969; Downs 1979; Einstein 1950; Hinshaw 1989; Moody 1990). Hinshaw (1989: 162) states: "The sciences are defined as bodies of human knowledge based on general principles about a delimited range of phenomena derived from empirical observation". The product or body of knowledge is the outcome or result of scientific inquiry (Parse 1987; Silva and Rothbart 1984) and includes scientifi terminology, definitions, propositions, hypotheses, theories and laws (Rudner 1966). As defined by Moody (1990:19) it is a body of knowledge which includes facts and theories generated by the use of systematic, controlled and precise methods within a defined area of concern.

As a process science refers to a method of inquiry or the means by which a body of knowledge evolves and progresses (Beckwith and Miller 1976; Bronowski 1965; Harrison 1984). Bronowski (1965:16) describes science as an intellectual activity and states "Science is nothing else than the search to discover unity in the wild variety of nature, or ... in the variety of our experience".

\section{WIIAT IS THE NATURE OF SCIENCE?}

The nature of science is a controversial issue. Conceptualisations vary according to the world view or philosophical orientation of the scientist. Two dominant world views of science are reflected in the literature, namely the "received view" and the "perceived view" of science. For decades the received view, also known as logical empiricism or positivism, was the predominantly accepted world view of science. In the literature it is frequently referred to as traditional science or pure science.

Proponents of the traditional view or logical positivism operate on strict rules of logic, truth, 
laws, axioms, predictions and reductionism. They believe that all human behaviour is objective, purposeful and measurable. Only what can be seen, sensed and measured is worthy of pursuing. Predictive statements that have no sensory data corroboration are not scientific. They hold the position that "truth" is absolute and there is a single reality. True statements are based on experience and known from experience. In order to find truth one must be completely objective, which means that values, feelings and personal perceptions cannot enter into the measurement of reality. According to logical positivists there is only one method for science. This method is detached observation, controlled experiment and mathematical or quantitative measurement (Van Manen, 1990:4) and incorporates logistic and deductive reasoning.

Facts from research are systematically linked to each other in a way that seems best to explain our empirical world; such linkages are called laws, principles or axioms depending on the certainty of the facts and relationship within the linkage. The emphasis of logical positivists is one of theory validation, not theory discovery (Rudner 1966).

Logical positivists do not address the application of science and therefore are accused of erecting barriers between the pure scientist and the scientific practitioner.

The perceived view of science, also known as historicism or postpositivism, evolved in reaction to the rather obvious limitations of traditional science or logical positivism and has gained increasing prominence since the $1960 \mathrm{~s}$. Historicists maintain that there is more to people than that which can be seen, sensed and measured. They believe it equally important to study and document what people know, experience and give meaning to both subjectively (internal reality) and objectively (external reality). Science is viewed as a process of understanding human bchaviour. "Understanding human expressions, knowing contextual experiences, and grasping the world view of people open the door to new and more meaningful insights about people" (Leininger 1985:23).

Historicists claim no access to certain truth or knowledge but rather accept certain knowledge to be "true", if it withstands practical tests of reason and utility. They do not cling to any one method of science but in fact encourage the use of the most appropriate method for the particular research question (De Groot 1988:8). Either qualitative or quantitative methods are seen as effective tools for the development of science and unlike traditional scientists, historicists hold values, aesthetics and ethics as an integral important part of the research tradition. According to this view legitimate knowledge can incorporate whatever is germane to the discipline, be it subjective, descriptive, normative, evaluative or objective.
Despite the differences in the conceptualisation of science by proponents of the received and perceived view of science, common threads in the characteristics, criteria and norms of science can be identified. Gortner and Schultz (1988) provide a list of well-accepted criteria for judging excellence in science which include significance, theory-observation, congruency, generalisability, reproducibility, precision and intcrsubjectivity. These criteria are applicable regardless of the methodological or philosophical approach used in developing the knowledge. A number of criteria which are interdisciplinary across the social sciences are often used as norms to judge the merit of the enquiry process and resultant knowledge base (Merton 1979; Barber 1952; Storer 1966). These criteria include universalism, commonality, disinterestness and organised scepticism. Hinshaw (1989) suggests that two additional criteria need to be used in judging excellence in science - the development or existence of substantiated bodies of knowledge specific to areas of critical concern in the profession, and the evolving information base on the "culting edge" of science - are both characteristics crucial to developing a creditable and usable science base.

These criteria may be useful in exploring whether or not and to what extent a science of nursing exists.

\section{WIIAT IS TIIE PURPOSE, GOAL OR AIM OF SCIENCE?}

For Kerlinger (1973) the major aim of science is to evolve theory which is conceptualised as a coherent set of verified relations useful for explanation and prediction, and consequently for control. Professional disciplines, however, expand on this and believe that the aim of science includes the development of prescriptive theory i.e. theory to guide practice.

\section{WIIAT IS A DISCIPLINE?}

Most of the definitions of science are posed in the context of the discipline from which they arise (Moody 1990:18). It therefore stands to reason that a consideration of science should include a consideration of the discipline from which it arises.

The Oxford dictionary defines discipline as "a branch of instruction or education; a department of learning or knowledge". In their now classic article "The discipline of nursing", Donaldson and Crowley (1978:414) maintain that disciplines have evolved as a consequence of a distinct perspective and syntax which determines what phenomena are to be viewed, what questions are to be raised scientifically, what methods of study are to be used and what evidence of proof is required.

According to Newman, Sime and Corcoran-Perry $(1991: 1)$ a discipline is distinguished by a domain of enquiry that represents a shared belief among its members regarding its reason for being. For example, the domain of enquiry for physiology is the study of the function of living systems, and for sociology it is the study of principles and processes goveming human society. The focus for law is injustice and grievance and the focus for architccture is the form and function of buildings. All research in these disciplines is directed towards addressing this focus in some small part. Each discipline thus has a central focus which influences the perspective of that field, the way it conceptualises the world and the question it poses for investigation. Donaldson and Crowley (1978:418) draw attention to the fact that even though each discipline is unique, they are not totally independent of each other. The quality of theories, research designs and validity of conclusions drawn within one discipline are dependent upon their congruence with all of knowledge. Therefore knowledge in one discipline may constrain or enhance the process of enquiry in another and no discipline should function in isolation. Donaldson and Crowley (1978:418) further distinguish between academic and professional disciplines. A professional discipline in addition to its area of study is defined by social relevance and value orientations. The focus is derived from a belief and value system about the profession's social commitment, nature of its service and area of responsibility for knowledge development. These requisites need expression in the focus statement. For example, while the central focus in medicine is disease, defect and physiological deficits, the social and value orientations of medicine as a professional discipline is conveyed by the commitment to alleviate disease.

\section{CONCEPTS RELEVANT TO THE FOCUS OF NURSING}

Nursing has defined itself as a discipline in order to establish identity separate from medicine (Murphy and Hoeffer 1983). Nurse theorists however, have not reached consensus yet on a central focus of enquiry clearly distinguishing it from other disciplines.

The domain of nursing was addressed by Yura and Torres in 1975 when they described the major concepts or the domain of nursing as being man, society, health and nursing. Although there are slight variations in terminology among theorists, there appears to be general agreement at present, at least in the USA and Canada, that the domain of nursing is person, environment, health and nursing. Fawcell (1984) and Jennings (1987) regard this as an important step in nursing theory development because it signifies that nursing has developed to the stage of identifying major ideas guiding common lines of enquiry. However, Hinshaw (1989:164) argues that "even with the commitment to and consensus concerning these four broad phenomena, knowledge to be developed and useful in 
practice will need to be much more specific in nature". Newman et al (1991) concur.

In recent years concepts of concern central to nursing have been defined or suggested by a number of professional nursing bodies in different parts of the world in their position or policy statements, and also by several nurse scholars who work mainly in the USA. For example, according to the position papers on nursing of the Royal College of Nursing (RCN), "caring", is the core of nursing. "The nursing system must acknowledge the centrality of care in the overall delivery of service ... it is the skill and art of caring for another person that transforms the action from a technique to a nursing intervention" (1987:11). The American Nursing Association (ANA) in its position paper on nursing regards the diagnosis and treatment of human response to actual and potential health problems as the central phenomenon of concern in nursing (1980:2). The Nordic Nurses Federation in their ethical guidelines for nursing research acknowledge nurses' responsibility to "promote health, to prevent illness, to restore health, to prevent death, and to assist to a comfortable dealh". Further there is a clear expectation for renewing personal knowledge and skills (1987:7). The SANC (1988) in its Philosophy and Policy statement on both professional basic and postbasic training state: "Within the parameters of nursing philosophy and ethics, nursing science is concerned with the development of knowledge for the nursing diagnosis, treatment and personalised health care of persons exposed to, suffering or recovering from physical or mental illness. It encompasses the study of preventive, promotive, curative and rehabilitative health care for individuals, families, groups and communities and covers man's life span from before birth". The International Council of Nurses (ICN) in a revised position paper on nursing research (1987) first specify a clear expectation for a constant generation of up-to-date organised nursing knowledge, and then state: "Nursing as an integral part of the health care system, encompasses the promotion of health, prevention of illness and care of the physically ill, mentally ill and disabled people of all ages in all health care and other community settings. Within this broad spectrum of health care, the phenomena of particular concern to nurses are individual, family and group responses to actual or potential health problems". The ICN thus concurs with the ANA regarding the phenomena of concern for nursing.

Allen (1987) has criticised the lack of clarity in the definition statement of the ANA, and suggests that rather than providing clarity, the statement may well serve to blur the direction of nursing science through a superficial definition of the scope of nursing. Packard and Polifroni (1991) are of the opinion that the defined focus does not distinguish clearly the domain of nursing from the domain of medicine. These arguments are equally applicable to the focus of concern defined by the other national bodies to which reference has been made.

The SANC has attempted to distinguish the domain of nursing from the domain of medicine by adding "within the parameters of nursing philosophy and ethics ... and developing knowledge for nursing diagnosis" - but did not elucidate these concepts. It is generally espoused that nursing adheres to a humanistic philosophy so it is not clear in which way nursing philosophy is a philosophy specific only to nursing and neither is it clear in which way nursing ethics are distinctive.

Either health or care or both feature prominently as the central focus of nursing in all the definitions referred to so far, as well as in current definitions of many nurse theorists and researchers. It can be argued that health has been heralded as the center picce of nursing knowledge since the days of Florence Nightingale and continues to be viewed as such by many nurse theorists and researchers (Meleis 1990; Newman 1986; Pender 1987). Caring, 100 , (both the concept and the process) has occupied a prominent position in nursing literature and has been suggested as the essence or central core of nursing, not only by the RCN but also by several nurse scholars (Benner and Wrubel 1989; Bottorf 1991; Leininger 1984; Watson 1985). The question which needs to be answered is whether either of these two concepts - health or caring, represents the central focus of the discipline of nursing. According to Peplau (in Smith 1988:82) we cannot say health is a central focus, because health is a goal, an outcome. In a recent editorial Diers (1988) disagrees with the premise of caring as the central focus, stating it is presumptuous of nurses to assume that only they care. Packard and Polifroni (1991) pose the question "If the aims of nursing science are directed towards the phenomena of caring, how is nursing different from other helping professions?". Newman et al (1991:2) argue that neither concept (i.e. health or caring) alone meets the criteria for the focus of the nursing discipline. For example, knowledge about health without consideration of caring, would be knowledge of a discipline of health and similarly, knowledge of personalised health care of persons exposed to suffering or recovering from illness would be knowledge of a discipline of health. These writers therefore suggest that the concepts, caring, health and health experience should be related to each other, to identify the domain of inquiry for nursing and submit that nursing is the study of caring in the human health experience (1991:3).

In a recent article Botes $(1991: 20)$ identifies the domain of nursing enquiry as "die mens betrokke by een of ander verplegingshandelinge". Translated, this would be man involved in one or other nursing activity. Similar arguments already voiced relating to lack of clarity and specificity would be applicable here too. What are nursing activities? How are they distinguished from medical or other health related activities? This view furthermore limits the scope of scientific inquiry of nursing; for example, historical studies of the evaluation of nursing practice or studies on the meaning of phenomena of concern to nursing are excluded. So far, the suggestion made by Newman et al (1991) seems one of the most meaningful regarding the focus of concern for nursing. The task remains to examine and explicate the meaning of caring in the human health experience in order to ascertain the adequacy of this focus for nursing, and to examine the philosophic and scientific questions provoked by the focus statements. Until such time, the issue of the central concern of nursing will remain unresolved. The position is taken that despite this shortcoming, great strides have been made in developing the discipline of nursing. As an evolving discipline, nursing is developing an organised body of knowledge, composed of specialised concepts and terminology used in education, practice and research. It has identified credible research methods, acceptable standards of practice, and criteria for educating practitioners in the field.

\section{DEFINITIONS OF NURSING SCIENCE}

Nursing Science, like science in general has been defined in several ways, which leads to confusion and may impede argumentation. In 1969 Abdellah described nursing science as "a body of cumulative scientific knowledge, drawn from the physical, biological and behavioural sciences that is uniquely nursing: (p.339). Almost a decade later Jacobs and Huether (1978:66) described nursing science as "the process and the result of ordering and patterning the events and phenomena of concern to nursing".

More recently Bottorf provided the following definition: "The term science of nursing refers to that branch or body of knowledge that is characteristically different from the knowledge that is aimed at and achieved by other discipline" (1991:28). Bottorf then emphasises that the science of nursing does not comprise all the knowledge that nurses need in order to practice (e.g. physiology, sociology) but rather, only that knowledge that is particular to nursing. These thrce writers thus all view nursing science differently. While Abdellah and Bottorf both agree that science is a body of knowledge - the focus of concern for accumulating this body of knowledge differs. On the other hand Jacobs and Huether support the viewpoint that science is a product created by a process "that is directly related". These variations in the conceptualisation of nursing science can cause considerable confusion to those wanting to defend nursing as a science.

The definition of nursing science by the SANC with its many labels for the term nursing 
science, further adds to this confusion. In its policy and philosophy on professional basic training the SANC describes nursing science as a human clinical heal th science that constitutes a body of knowledge ... is concerned with the development of knowledge ... is an area of sludy ... and the scientific approach is also referred to as the nursing process. Nursing science can thus refer to any of five phenomena.

Carper (1978) described a convenient way of vicwing the kind of knowledge necessary in nursing by identifying fundamental patterns of nursing. The four fundamental patterns she identified are:

\section{(1) Empirics - the science of nursing}

\section{(2) Aesthetics - the art of nursing}

(3) Personal knowledge - interpersonal knowing concerned with the kind of knowing that promotes wholeness and integrity in the personal encounter and the achievement of engagement rather than detachment, and

(4) Ethics - the component of moral knowledge in nursing

These patterns are useful for structuring knowledge in nursing and indicate areas for establishing a useful body of knowledge for nursing. Chinn (1985) wrote extensively in upport of Carper's patterns of knowing and refuted the superiority of empirical knowledge as the only relevant science. It would appear that the non-restrictive definition of science suggested by Moody (1990:19), but substituting Carper's four fundamental patterns of nursing for Moody's defined area of concern, could serve as an excellent guideline for nurses.

\section{TIIE ISSUE OF NURSING AS A BASIC VS APPLIED OR PRAC'TICE SCIENCE}

The question whether nursing is a basic, applied or practice science is a further issue of frequent controversy and confusion. Currently three positions regarding the nature of nursing science can be found in the nursing literature. It held that nursing is a basic science, an applied science or a practical science. Arguments can be advanced for and against each of these three positions.

The basic sciences generally are distinguished from other sciences on the basis of their goal or end. The goal of basic science is theory or knowledge for the sake of knowledge. Basic science serves as a pool of knowledge and does not offer guidance per se. Proponents of nursing as a basic science limit scientific enquiry in nursing to description, explanation and understanding (Gortner and Schultz 1988; Moccia 1988; Parse 1981; Peplau 1988; Rogers 1988). Scientific effort should be focused on abstract knowledge that clarifies the domain of nursing (c.g. what is the meaning of health or caring or the historical evolution of holistic health care). However, if nursing science is pursued only as a basic science, nursing practice will be without the scientific understanding of nursing means. Without scientific knowledge of nursing, the nurse is left to her or his own resources and to using trial and error to determine how descriptive knowledge should be applied in a particular situation. Basic scientific knowledge does not provide the nurse with the necessary knowledge to make decisions about the most effective course to follow in meeting a goal. Some scholars have argued that nurses should not impose their own views on their clients and limit knowledge claims to those which are purely descriptive. Moccia, for example argued that the use of knowledge that is predictive strips individuals of their potential for autonomous self-determination and reduces them to objects. She expresses concern regarding the view that science should guide practice and asks whether it is not immoral 10 impose a belief system on another individual. However, in retaliation the question of whether it is immoral to subject humans to a trial and error practice in nursing also needs to be addressed.

In reaction to the apparent inconsistencies and inadequacies of nursing as a basic science, nursing is regarded by many as an applied science. Questions however, arise in respect to a common determination of what is really meant by the term applied science. In the nursing literature it has been given a variety of meanings. Some view applied science as answering questions related to the applicability of basic theories in practical siluations, rather than questions related to how basic theories are to be applied (Donaldson and Crowley 1978). Some suggest that an applied science is one that uses the knowledge of basic sciences for some practical end (Wallace 1983). Some refer to applied science as theories derived from the scientific theories of other disciplines that are applicable to nursing (Meleis 1988). In the light of the ambiguity surrounding the term "applied" science. the term as related to nursing is in need of clarification. On the other hand, there remains the question of "applying what" - only nursing theories or theories from other disciplines? And also, there is the question as to whether being an applied science eliminates the potentialities of basic science.

Ilistory demonstrates that some of the most important scientific discoveries come about inadvertently and not as a direct result of specific research aims. Further, theory has ofien preceded application by many years, as for example in the case of nuclear physics and Mendel's law. In labelling nursing as an applied science and limiting scientific inquiry to the application of basic sciences to nursing practice, the science of nursing is made dependent on advancements in other disciplines. It is however, unlikely that all scientific knowledge essential for nursing practice will be developed by other disciplines. If nurses pursue nursing science as an applied science, nurse scientists may be forced to wait indefinitely for development of scientific principles that can be tested and applied to nursing practice.

The third conceptualisation of nursing scieno to be considered is that of nursing as a practical science. In recent literature Orem (1988) and Schlotfeld (1988) argued that the science of nursing must be practical. Scientific inquiry in nursing must yield findings directly useful and relevant to nursing practice. Practical knowledge presupposes theoretic knowledge. As Wallace (1983:277) stated "Sciences are said to be practical because their knower intends operation, while they are also said to be theoretical because their knower intends truth and proceeds analytically, even though the science as such is concemed with something doable". When nursing science is conceptualised as a practical science, it is clear that nursing's ultimate goal is to use knowledge of principles and causes in the development of specific nursing means that can achieve nursing ends and thereby the overall end of nursing. A practical science generates descriptive, explanatory, predictive and prescriptive theory and therefore can be considered suitable to meeting nursing's needs. Botes (1991) advocates the use of the functional approach in nursing science. Exopt for the terminology her explication of the functional approach appears to be more or less equivalent to descriptions of practical science in the American and Canadian litcrature.

The implication of calling nursing a practice science is that the focus of nursing, in providing a particular service, should be a special consideration in the development of nursing knowledge. While this observation is obvious, there is reason to question the utility and appropriateness of advancing arguments pertaining to basic vs practice science.

Toulmin (1972) pointed out that all scientific enterprises are made up of two components, viz.:

(1) the body of knowledge

(2) the group of individuals who work to apply, develop and evaluate that knowledge

The notion of a practical discipline might be considered universal, for even historians and mathematicians have a "practice" component as they work to apply the knowledge in their respective fields. It is difficult to argue against Toulmin's view of science because a body of knowledge must be knowledge for some group of people. Consequently following Toulmin's view, the distinction between a basic and applied or practice discipline offers little contribution to understanding the nature of nursing. Al disciplines must have an associated group of persons who use and develop the 
knowledge base, whether their "practice" realm is in a laboratory or in a community with human recipients (Rodgers 1991:180). Debates on nursing as a basic or applied or practice science thus appear to offer little contribution to supporting the view that nursing is a science.

\section{NURSING SCIENCE METIIODS}

The decision regarding an acceptable method to be used in the conduct of scientific enquiry in nursing has been subject to considerable debate. Some writers believe that empiricism if not quantification is the most appropriate avenue for research endeavours (Clarke and Yaros 1988; Moccia 1988; Norbeck 1987). Others (Field and Morse 1985; Leininger 1985) maintain that the qualitative approach holds the greatest promise. Several writers have advocated the use of both qualitative and quantitative approaches within the same study and for the same questions (Duffy 1987; Gortner and Schultz 1988; Porter 1989). In response, a number of writers including Moccia (1988) and Phillips (1988) address the overall loss of integrity inherent in using opposing methods. Proponents of the quantitative methods seem to agree that is is not the only way to go about research, but it is important in that statistical data allow us to see what portion of the dependent variable is explained by the identified independent variables. Those who favour qualitative methods believe that first hand experience provides the most meaningful data for nursing.

Leininger (1985:2) encapsulates the views of the proponents of this approach in stating "the scientific method is far too narow, reductionistic and controlled to let one know human beings in their totality and help them in times of wellness and illness". Those theorists and scholars who support a position which espouses the values of both methodologies, particularly in combination, seem to believe that it is too early in the development of nursing to put closure on any type of methodology.

1 would support this latter view. Nursing is a complex and diverse phenomenon and has a great variety of questions confronting it today. The many types of qualitative and quantitative methods all have valuable and unique contributions to make. Al methods should be given equal respect and support by all members of the discipline of nursing. The purpose of the research should dictate the approach to be used.

\section{IS EXCELLENCE IN NURSING SCIENCE SUSTAINED?}

Gortner and Schultz (1988) believe the emphasis in debates on nursing as a science should be on standards of "good science" in nursing regardless of technique. Thus the issue of concern is to what extent does nursing science meet the accepted criteria for judging scientific merit? To answer this, the criteria advanced by
Hinshaw (1989:169) to judge excellence in nursing science, namely depth in the knowledge base and studies which are on the "culting edge" of knowledge frontiers, will be examined in telation to the present state of nursing science.

Depth in the knowledge base refers to a series of studies in the same or common areas of investigation which provide evidence of similar results. Only if replicated findings are present across several studies under different as well as similar conditions, can professionals be reassured that the information is credible and useful, and only if the findings have been publicised and criticised and consensus has been reached by a community of scholars can professionals be reassured that their information is significant. The historical pattern in nursing research both here and abroad has been a more shotgun approach - one study in an area of interest followed by one in another area of investigation. With very few exceptions there is no series of nursing studies in the same or common areas of investigation. If there are more than two or three studies in the same area they generally were all done in isolation and do not link with each other. Nurses are not yet dedicated to basing new research efforts on previous knowledge, yet a cumulative body of knowledge includes building on colleagues as well as one's own research. With regard to publicising and criticising, more nurses are coming forth and publishing their research peers however, are not forthcoming in criticising and with a few exceptions researchers and writers are not yet ready to accpet criticism. or otherwise are oversensitive to it.

Being on the cutting edge of knowledge frontiers requires that nurse researchers be in the forefront with their knowledge of the substantive area as well as the methods needed for their field of study. To remain on the "cutting edge" of any scientific field requires continual learning and relearning. Nurses are aware of this and are paying active attention to improving themselves continuously. A second strategy for staying on the forefront of the developing scientific body of knowledge is maintaining strong relationships with interdisciplinary colleagues in relevant fields of study. Hinshaw (1990:23) states "nursing research cannot afford to be developed in a vacuum only to discover that valuable resources such as time, energy and money have been spent in recreating information already known by other disciplines". Commonality or the sharing of ideas and research endeavours is one of the major criteria to judge the merit of science which is interdisciplinary across the social sciences. Do nurses in this country collaborate sufficiently with colleagues from other disciplines when doing research? Not much evidence exists at present to provide an answer. Universalism which is another criterion advocated for judging the merit of science requires that knowledge be generalisable to more and more of the universe. Yet are nurses not inclined to confine themselves to a limited context and solve problems locally without extracting principles which may hold universally? Another vital component of science is scepticism - the recognition that all knowledge is uncertain and therefore the ability to suspend judgment and to feel and express doubt is important. Are nurses perhaps still too eager to hold their findings as facts regardless of whether they can justify their credibility, rather than welcome criticism about them, and criticise then themselves? Science is also characterised by accuracy and precision and terms specific to the system are defined for clarity and precision. Uniformity of usage provides for communication. In nursing there is still room for much improvement regarding these criteria. We have so many terms to cover exactly the same concept. We coin new terms to cover what has previously been discussed in another setting and in another field and do not define them adequately. We almost have reached a stage where nobody is understanding anybody.

\section{CONCLUSION}

The nursing scientific community is confronted with the challenge of developing knowledge for the discipline with scientific rigor and integrity and to defend its position in relation to other disciplines. So far it has grappled with many issues - confusion regarding terminology, it central focus of concern, diversity regarding the nature and purpose of nursing, methods to be used in developing nursing science and the question of sustaining excellence in nursing science. Valid arguments for and against the positions taken have been advanced. In the eyes of purists i.e. adherents of traditional science or logical positivism nursing will not qualify as a science, as nursing knowledge is not consistent with these views. Nursing has humanistic or naturalistic components that are incompatible with such a conception of science. Recent writings in philosophy have provided a substantial basis for the rejection of such views, but nevertheless current writers support an expanding view of science allowing for the introduction of naturalistic orientation with a wider range of methods, a more flexible conception of theory, and in general a broader view of what science is. This form accommodates the previously debatable forms of nursing science and enables attention to be given 10 many forms and methods of enquiry. With the multiplicity and diversity of phenomena in nursing, it is imperative to use more than one method of approaching and understanding them. Anything that values exclusively one standard as superior (whether a language, race gender or science) restricts its ability to progress behond the boundaries it self-imposes. There is always growth and discovery beyond the boundaries and there cannot be only one best view or one best method in developing a science. There should however, be one central focus of concern to direct nurse 
researchers and nurses should reach consensus about this. It is also important to re-examine continually our scientific progress and to evaluate the scientific merit of our developing body of knowledge. Nurses need to deal with the challenge to assure excellence in nursing science. To accumulate knowledge which is creditable and usable, nurse scientists need to build on colleague's as well as their own research. They need to generate multiple studies in specific content areas and they need to publicise, criticise and question ideas and to strive to extend each others endeavours. They need to keep in step with developments in the philosophy of science and their subject area as well as to maintain strong relationships with interdisciplinary colleagues in relevant fields. Above all they need to ensure that the science of nursing is rellevant to the art of nursing.

\section{REFERENCES}

ABDELLAH, F.G. 1969. The nature of nursing science. Nursing Research 18 (no.5): 393-399.

ALLEN, D.G. 1987. The social policy statement: A reappraisal. Advances in Nursing Science 10 (no.1): 39-48.

AMERICAN NURSESASSOCIATION. 1980 Nursing: A social policy statement. Kansas City M.O.: ANA

BARBER, B. 1952. Science and the Social Order. New York: Collies.

BECKWICK, J. AND MILLER, L. 1976. Behind the mask of objective science. The Sciences 16: 16-19.

BENNER, P. AND WRUBEL, J. 1989. The Primacy of Caring. Menlo Park California: Addison-Wesley.

BOTES, A. 1991. 'n Funksionele denkbenadering in die verplcegkunde. Curationis. 14 (no. 1): 19-23.

BO'TIORF, J.L. 1991. Nursing: A practical science of caring. Advances in Nursing Science 14 (no. 1): 26-39.

BRONOWSKI, J. 1965. Science and Human Values. New York: Julia Messner.

CARPER, B.A. 1978. Fundamental patterns of knowing in nursing. Advances in Nursing Science 1 (no. 1): 13-23.

CHINN, P.L. 1985. Debunking myths in nursing theory and research. Image 17 (no. 2): $45-49$.

CHINN, P.L. \& JACOBS, M.K. 1987. Theory and Nursing. 2nd Edition. St Louis: Mosby.

CLARKE, P.N. AND YAROS, P.S. 1988. Commentary: Transitions to new methodologies in nursing science. Nursing Science Quarterly 3:147-151.

DE GROOT, H. 1988. Scientific enquiry in nursing: A model for a new age. Advances in Nursing Science 10 (no. 3):1-21.
DIERS, D. 1988 . On clinical scholarship. Image 20 (no. 1): 2.

DONALDSON, S.K. \& CROWLEY, D.M. 1978. The discipline of nursing. Nursing Oullook 26 (no. 2): 113-120.

DOWNS, F. 1979. Clinical and theoretical research in F.S. Downs \& J.W. Fleming (eds) Issues in nursing research 67-89. New York: Appleton-Century Crofts.

DUFFY, M.E. 1987. Methodological triangulation: A vehicle for merging quantitative and qualitative research methods. Image 19 (no.2): 130-132.

EINSTEIN, A. 1950. Out of my later years. New York: Philosophical library.

FAWCETT, J. 1984. The metaparadigm of nursing: Present status and future refinements. Image 16 (no. 2): 84-87.

FIELD, P.A. AND MORSE, J. 1985. Nursing Research: The application of qualitative approaches. Rockville, M.D. Aspen Systems.

GORTNER, S. (ed). 1987. Nursing science methods: A reader. San Francisco: University of California.

GORTNER S.R. AND SCHULTZ, P.R. 1988. Approaches to nursing science methods. Image 20 ( no. 1): 22-27.

GOR'TNER, S.R. 1990. Nursing values and science: Toward a science philosophy. Image 22 (no. 2): 101-105.

GREENE, J. 1979. Science, nursing and nursing science: A conceptual analysis. Advances in Nursing Science 2 (no. 4): 57-64.

HARRISON, A.J. 1984. Science, engineering and technology. Science: 223-543.

HINSHAW, A.S. 1989. Nursing science: The challenges to develop knowledge. Nursing Science Quarterly 2 (no. 4): 162-171.

JACOBS, M. AND HUETHER, S. 1978. Nursing science: The theory practice linkage. Advances in Nursing Science 1 (no. 1): $63-73$

JACOX, A. 1974. Theory construction in nursing: An overview. Nursing Research 12: (no. 1): 6.8 .

JENNINGS, B.M. 1987. Nursing theory development, successes and challenges. Journal of Advanced Nursing 12: (no. 1):63-69.

KERLINGER, F. 1973. Foundations of Behavioural Research. N.Y.: Holt, Rinehart \& Winston.

KLEMKE, E.D., HOLLINGER, R. AND KLINE, A.D. 1980. Introductory readings in the Philosophy of Science. Buffalo: Promctheus.
LEININGER, M.M. (ed). 1984. Care: The essence of Nursing and Healih. Thorofare, N.J.: Slack.

LEININNGER, M.M. 1985. Qualitative Research Methods in Nursing. Orlando: Grune and Stratton.

MELEIS, A.I. 1990. Being and becoming healthy: The care of nursing knowledge. Nursing Science Quarterly 3 (no. 3): 107-114.

MERTON, R.K. 1979. The sociology of science: An episodic memoir. Cartondale: Southern Illinois. University Press.

MOCCIA, P. 1988. A critique of compromise: Beyond the methods debate. Advances in Nursing Science 10 (no. 4): 1-9.

MOODY, L.E. 1990. Advancing Nursing Science through Research. Vol. 1. Newbury Park: Sage Publications.

MUNHALL, P.L. AND OILER, C.J. 1986. Nursing Research: A qualitative perspective. Norwalk/Connecticut: Appleton Century Croft.

MURPHY, S. AND HOEFFER, B. 1983. Role of the specialities in nursing science. Advances in Nursing Science 5 (no. 4): 31-39.

NEWMAN, M.A. 1986. Health as Expanding Consciousness. St. Louis: Mosby.

NEWMAN, M.A. 1991. Health conceptualisations and related research. Annual Review of Nursing Research 1991 : 9.

NEWMAN, M.A., SIME, M. AND CORCORAN-PERRY, S.A. 1991. The focus of the discipline of nursing. Advances in Nursing Science. 14 (no. 1): 1-6.

NIGHTINGALE, F. Reprint 1969. Notes on nursing: What it is and what it is not. New York: Dover Publications

NORBECK, J.S. 1987. In defense of empiricism. Image 19 (no. 1): 28-30.

NORDIC NURSES FEDERATION. 1987. Ethical guidelines for nursing research in the Nordic countries. Aurskog, Norway: Printing Data Center

OREM, D.E. 1988 . The form of nursing science. Nursing Science Quarterly 19 no. 2): 75.79 .

PACKARD, S.A. AND POLIFRONI, C. 1991. The dilemma of nursing science: Current quandaries and lack of direction. Nursing Science Quarterly 4 (no. 1): 7-13.

PARSE, P.R. 1981. Man-living-health: A theory of nursing. New York: Wiley.

PARSE R. 1987. Nursing Science: Major paradigms, theories and critiques Philadelphia: W.B. Saunders. 
PENDER, N.J. 1987. Health promotion in nursing practice. Norwalk/Connecticut: Appleton-Lange.

PIIILLIPS, J.R. 1988. Research Blenders. Nursing Science Quarterly. 1: (no. 1): 4-6.

POLKINGHORNE, D. 1983. Methodology for the human sciences: Systems of enquiry. Abany: New York State, University of New York Press.

PORTER, E.J. $1989 . \quad$ The qualitative-quantitative dualism. Image 21 (no. 2): 98-102.

RODGERS, B.L. 1991. Deconstructing the dogma in nursing knowledge and practice. Image 23 (no. 3): 177-181.

ROGERS, M.E. 1988. Nursing Science and art: A perspective. Nursing Science Quarterly 1 (no. 3): 99-102.

ROYAL COLLEGE OF NURSING 1987. In pursuit of excellence. A position statement on nursing. London: RCN.

RUDNER, R.S. 1966. Philosophy of social science. Englewood Cliffs: N.J. Prentice-Hall.

SANC. 1988. Guidelines for the course leading to registration as a nurse (general, psychiatric and community) and midwife 55/M88. Pretoria: SANC.
SARNECKI, M.T. 1990. Historiography: A legitimate research methodology for nursing. Adwances in Nursing Science 12 (no. 4): 1-9.

SCHLOTFELD, R.M. 1988. Structuring nursing knowledge: A priority for creating nursing's future. Nursing Science Quarterly 1 (no. 1 ): $35-38$

SILVA, M.C. 1977. Philosophy, science, theory: Interrelation-ships and implications for nursing research. Image 9 (no. 3): 59-63.

SILVA, M.S. AND ROTHBART, D. 1984. An analysis of changing trends in philosophies of science on nursing theory development and testing. Advances in Nursing Science 6 (no. 2): 1-13.

SMITH, M.J. 1988. Perspectives on nursing science. Nursing Science Quarterly. 1 (no. 3): $80-85$

STORER, N.W. 1966. The social system of science. New York: Holt, Rinehart, Winston.

SUPPE, F. 1977. The structure of scientific theories. 2nd edition. Chicago: University of Illinois

TOULMIN, S. 1972. Human understanding. Princeton: Princeton University.

WALLACE, W.A. 1983. From a realist point of view. Essays on the philosophy of science. 2nd edition. Washington. D.C University Press of America.

WATSON, J. 1981. Nursing's scientific quest. Nursing Outlook. 29 (no. 7): 413-416

WATSON, J. 1985. Nursing: The philosophy and science of caring. Boulder: Colarado Associated University Press.

VAN MANEN, M. 1990. Researching lived experience. New York: The State University of New York

YURA, H. AND TORRES C. 1975. Today's conceptual framework with the baccalaureate nursing programs. (N.L.N. Publication No. $15-1558$ pp. 17-75). New York: National League for Nursing.

Hilla Brink D Litt. et Phil. R.N. R.M. R.T. R.NA. R.C.H.N.

Professor in Nursing Science University of South Africa Pretoria. 